\title{
TUTA ABSOLUTA (MEYRICK) (LEPIDOPTERA: GELECHIIDAE) - BIOLOGY, ECOLOGY, PREVENTION AND CONTROL MEASURES AND MEANS IN GREENHOUSE TOMATO CROPS. A REVIEW
}

\author{
Simona Ştefania Hogea ${ }^{1 *}$ \\ ${ }^{1}$ Research and Development Institute for Vegetable and Flower Growing, Vidra, \\ Calea Bucureşti, no.22, Ilfov, Romania
}

Current Trends in

Natural Sciences

\begin{abstract}
The tomato leafminer, Tuta absoluta (Meyrick) is a dangerous pest, difficult to control in tomato crops. In Europe, it was originally reported in eastern Spain, at the end of 2006, subsequently spreading very fast throughout the Mediterranean basin and in various countries in Europe. In Romania, was first reported in 2009, in the North West area (Satu Mare), and a year later he was identified near Bucharest, in greenhouse crops. The larvae attack both foliage and fruit during all tomato growth stages. On leaves, larvae feed only on mesophyll, leaving the epidermis intact. They also penetrate into tomato fruits where they feed and grow, leaving behind mines and galleries. The species of vegetables from Solanaceae family are the main hosts of the pest. Control of Tuta absoluta infestations is difficult to achieve, because the larvae are protected in the leaf mesophyll or inside the fruits. Chemical control is the primary method to manage the pest, but there are also alternative methods of control, less polluting, such as: biological control through treatments with biological products, by releasing of parasitoids and predators, insect-proof nets, pheromone traps and so on. Treatments must be applied before the pest penetrates under the epidermis of the leaves or in fruits.
\end{abstract}

Keywords: integrated control, pest, tomato leafminer

\section{INTRODUCTION}

Tuta absoluta (Lepidoptera: Gelechiidae), known as the tomato leafminer, is a very important pest of tomato crops (Braham and Hajji, 2012). It was originally described as Phthorimaea absoluta by Meyrick in 1917, a male specimen being collected from Peru (Ferracini et al., 2019).

According to the literature, in the last 10 years, tomato crop infestation has increased from $3 \%$ to $60 \%$ worldwide (Biondi et al., 2016), so it can reduce yield by more than $90 \%$ (Batalla-Carerra et al., 2010), and in cases where effective control methods are not used, losses of $100 \%$ may be recorded (Biondi et al., 2016). It is considered a key pest of tomato crops in greenhouse and fields (Cocco et al., 2012).

The species of the Solanaceae family are the main host of the pest, tomato, potato and European black nightshade being the most suitable (Abbes et al., 2016; Desneux et al., 2010; Biondi et al., 2016), but it can also attack eggplants, peppers and tobacco (Mohamadi et al., 2017). At the same time, it can lay eggs and grow on other species of plants in the families: Amaranthaceae, Convolvulaceae, Fabaceae and Malvaceae (Biondi et al., 2016). 


\section{Current Trends in Natural Sciences}

Vol. 9, Issue 17, pp. 222-231, 2020

https://doi.org/10.47068/ctns.2020.v9i17.028

Current Trends in Natural Sciences (on-line)

ISSN: 2284-953X

ISSN-L: 2284-9521
Current Trends in Natural Sciences (CD-Rom)

ISSN: 2284-9521

ISSN-L: 2284-9521

The larvae attack both foliage and fruit during all tomato growth stages. On leaves, larvae feed only on mesophyll, leaving the epidermis intact. They also penetrate into tomato fruits where they feed and grow, leaving behind mines and galleries (Braham and Hajji, 2012). The galleries produced by T. absoluta are found on the apical buds, on the stems and on the green and ripe fruits (Moreno et al., 2017).

The species spreads very quickly, from one area to another, by wind which favors the spread of the pest in new areas (Desneux et al., 2011; Zekeya et al., 2017). This type of spread is an advantage for the pest, its energy being available for reproduction (Gontijo et al., 2013; Cascone et al., 2015; Zekeya et al. 2017). T. absoluta can fly several kilometers and can be accidentally dispersed by humans in local or global crops areas through trade with infested tomatoes (Tropea et al., 2012; Bayram et al., 2015, Bettaibi et al., 2012; Zekeya et al., 2017).

This pest was originally reported in eastern Spain, at the end of 2006, subsequently spreading very fast throughout the Mediterranean area and in various countries in Europe (Desneux et al., 2010). In Romania, it was first reported in 2009, in the North West part (Satu Mare) and a year later it was identified near Bucharest, in greenhouse tomato crops (Bratu et al., 2015).

Losses caused by T. absoluta and its rapid spread in most areas of tomato cultivation in the world are possible due to the ability of the species to adapt to different environmental conditions (Martins et al., 2016).

\section{BIOLOGY AND ECOLOGY}

The main host of the pest is tomatoes, but it can also attack eggplants (Mohamadi et al., 2017; fig. 1, fig. 2).

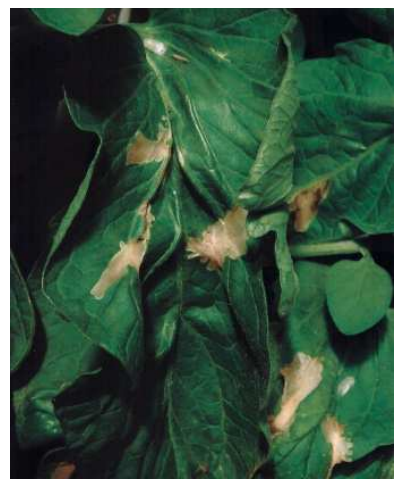

Figure 1. Tuta absoluta attack on tomato leaves

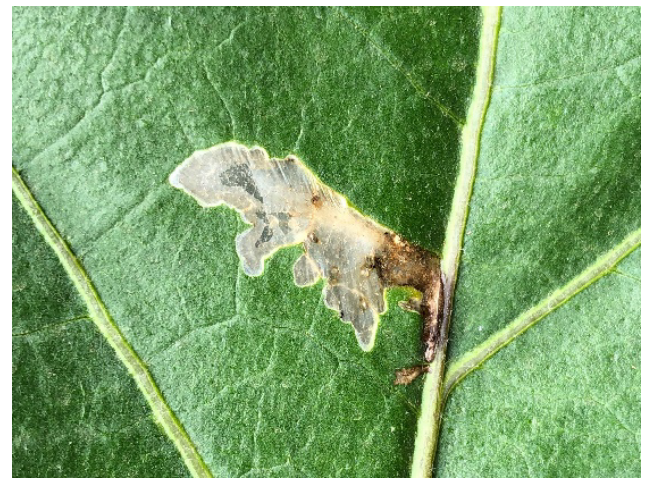

Figure 2. Tuta absoluta attack on eggplant leaf

Under greenhouse conditions it can develop 10-12 generations/year (Desneux et al., 2010).

The optimal temperature for development is $30^{\circ} \mathrm{C}$, and the life cycle varies between 26 and 75 days (Biondi et al., 2016), having four stages of development: egg, larva, pupa and adult (Desneux et al., 2010).

Females usually lay eggs on the leaves (Batalla-Carrera et al., 2010), being individual or, less frequently, grouped (Torres et al., 2001), on the underside of the leaves to protect them from birds or from unfavorable environmental conditions for their development (Sinclair and Hughes, 2010; Balzan and Moonen, 2015; Zekeya et al., 2017). Immediately after laying, eggs are yellowish becoming coppery-red and with two red eye-spots about one day before hatching (Torres et al., 2001). They are found on young leaves, sepals or stems (Biondi et al., 2016). The incubation period 


\section{Current Trends in Natural Sciences \\ Vol. 9, Issue 17, pp. 222-231, 2020 \\ https://doi.org/10.47068/ctns.2020.v9i17.028}

Current Trends in Natural Sciences (on-line)

ISSN: 2284-953X

ISSN-L: 2284-9521
Current Trends in Natural Sciences (CD-Rom)

ISSN: 2284-9521

ISSN-L: 2284-9521

is between 4 and 7 days at $27^{\circ} \mathrm{C}$. Neonate caterpillars are pale becoming green during the second and third instars, and the abdomen is green and the thorax purple during the fourth instar. They have a body length of $7-10 \mathrm{~mm}$ at end of the later stage (Torres et al., 2001). The larvae of the fourth instar live in leaf galleries, where they feed and grow (Batalla-Carerra et al., 2010; fig. 3; fig. 4). The larvae directly affect the leaves, terminal buds, flowers and fruits (Haji et al., 1988; Lopes Filho, 1990; Castelo Branco, 1992; Souza and Reis, 1992; Torres et al., 2001; fig. 5). The mature larvae usually fall and penetrate into the soil where they produce a thin, silky cocoon that turns into prepupae and pupae (Biondi et al., 2016).

Pupae (5 - $6 \mathrm{~mm}$ long) have a cylindrical shape and are green (Desneux et al., 2010) and later become brownish and have a development time of 7-9 days (Torres et al., 2001). Pupae are normally found in the soil, but can also be identified on plants (Batalla-Carrera et al., 2010). In the soil, the pupae are protected from chemicals and high temperatures on days with strong sunshine (Sinclair and Hughes, 2010; Balzan and Moonen, 2015; Zekeya et al., 2017).

Adults have $6-7 \mathrm{~mm}$ in length and filiform antennae. Black spots are found on anterior wings, and females are bigger and more voluminous than the males (Desneux et al., 2010; fig. 6).

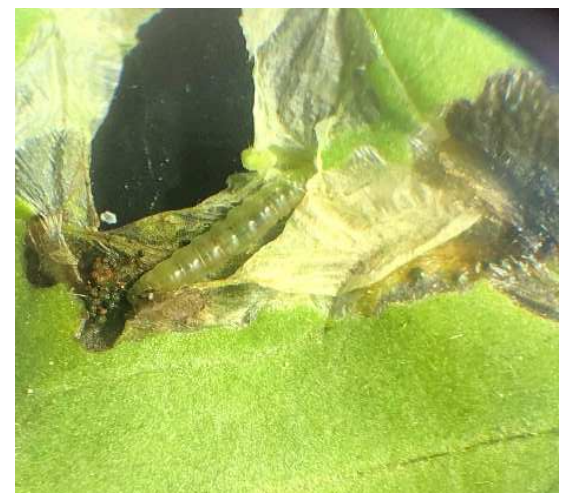

Figure 3. Tuta absoluta - larva

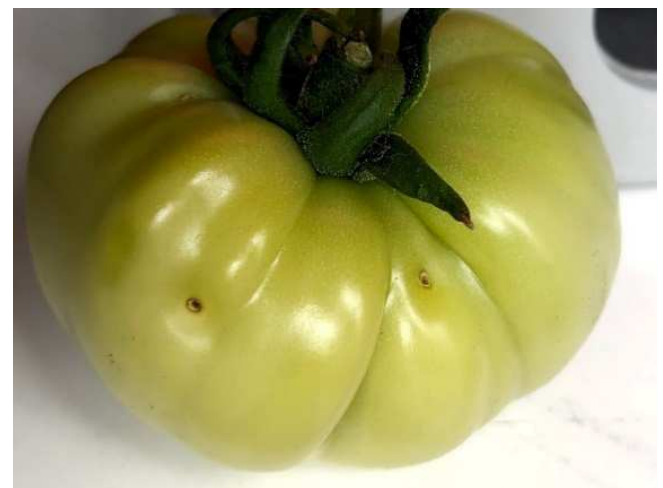

Figure 5. Tuta absoluta attack on tomato fruit

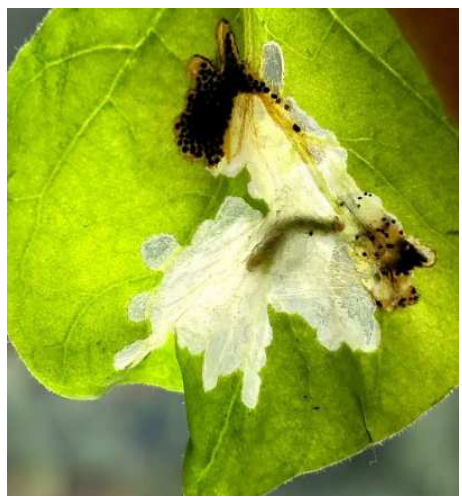

Figure 4. Tuta absoluta - larva and excrements

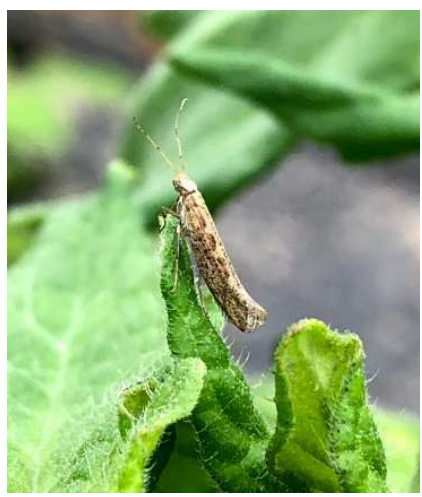

Figure 6. Tuta absoluta - adult

Females live 10 to 22 days and can lay between 60 and 120 eggs. The species needs 29-38 days to complete cycle, depending on the temperature (Batalla-Carrera et al., 2010).

The pest is active at night and adults usually remain hidden during the day, having an intense activity in the morning (Desneux et al., 2010). 
The length of the development cycle depends very much on the climatic conditions, the average development time being 76.3 days at $14^{\circ} \mathrm{C}, 39.8$ days at $19.7^{\circ} \mathrm{C}$ and 23.8 days at $27.1^{\circ} \mathrm{C}$ (Barrientos et al., 1998). These data were obtained based on the determination of the temperature thresholds and the thermal constant for T. absoluta. Temperature thresholds for eggs, larvae and pupae were estimated at $6.9 \pm 0.5^{\circ} \mathrm{C} ; 7.6 \pm 0.1^{\circ} \mathrm{C}$ and $9.2 \pm 1.0^{\circ} \mathrm{C}$, respectively. The threshold for eggs-larvaeadults is $8.1 \pm 0.2^{\circ} \mathrm{C}$ (Desneux et al., 2010). The life cycle was reduced from 75 to 26 days when the temperature ranged from 17 to $33^{\circ} \mathrm{C}$ (Martins et al., 2016).

At the temperature of $7^{\circ} \mathrm{C}$ there was no egg which hatched, but at $10^{\circ} \mathrm{C}, 17 \%$ of them successfully hatched. Eggs kept at $13^{\circ} \mathrm{C}$ had the highest hatching percentage $(92 \%)$, and it was significantly higher only at $19^{\circ} \mathrm{C}$. At temperatures between $13^{\circ} \mathrm{C}$ and $23^{\circ} \mathrm{C}$ a hatching percentage of more than $80 \%$ was obtained, under fluctuating temperatures, with a daily average of $21^{\circ} \mathrm{C}$. There was a significant decline in egg hatching above $23^{\circ} \mathrm{C}$ (Cuthbertson et al., 2013).

\section{PREVENTION AND CONTROL MEASURES AND MEANS}

The use of ,insect-proof" nets and the removal of the organs of the attacked plants (leaves, fruits) from tomato crops are two important measures to prevent the spread of the pest attack. These measures are usually combined with other cultural practices: solarization to destroy pupae from the soil, covering the ground with a plastic wrap to prevent the emergence of adults from the pupae from the soil, destroying secondary host plants inside and around protected areas (Abbes et al., 2012).

There are also alternative and less polluting control methods, such as: use of light traps, synthetic pheromone traps for male annihilation or mating disturbance (with these synthetic pheromone traps, the ability of males to identify females is disturbed, thus reducing population density), microbiological control and biological control with parasites and predators (Cocco et al., 2012).

Light traps attract both males and females. Seasonal catches showed that in crops, males appear about a week earlier than females. These traps are more effective for catching males (Altermatt et al., 2009; Aksoy and Kovanci, 2016).

Pheromone traps can be used for early detection of the tomato leafminer in recently infested areas (Machekano et al., 2018, Mansour et al., 2018). When the pest settles in an area, the same traps can be used to monitor the population. This involves monitoring the flight activity during the growing season, in order to establish the optimal time for the application of insecticide treatments or, alternatively, biological control (Caparros Megido et al., 2013; Mansour et al., 2018).

The most commonly used type of pheromone trap is the Delta trap (fig. 7, fig. 8) which consist of triangular-shaped body open at ends. Inside is a removable tray with adhesives and in the middle of it is positioned the bait with pheromones (Caparrros Megido et al., 2013).

Biological control can be achieved with the following products: Laser $240 \mathrm{SC}$ (spinosad $240 \mathrm{~g} / \mathrm{l}$ ) 0.05\%, BactoSpeine DF (Bacillus thuringiensis subsp. kurstaki 54\%) 0.06\%, Oleorgan (Neem oil 40\%) 0.3\%, Quamar (Quassia amara extract 75\%) 0.3\%, Konflic (Quassia amara 50\% + potassium salt 50\%) $0.3 \%$ (Costache et al., 2018).

In European countries where the attack of this pest occurs with high frequency, predatory species have been reported, especially from the order Hemiptera (10 species), belonging to the families Miridae, Anthocoridae and Nabidae (Zappalà et al., 2013; Ferracini et al., 2019).

Several predatory species, such as Dicyphus errans, Dichypus bolivari, Macrolophus pygmaeus, Nesidiocoris tenuis and Nabis pseudoferus, have been evaluated as natural enemies of the tomato leafminer (Ferracini et al., 2019). 


\section{Current Trends in Natural Sciences}

Vol. 9, Issue 17, pp. 222-231, 2020

https://doi.org/10.47068/ctns.2020.v9i17.028

Current Trends in Natural Sciences (on-line)

ISSN: 2284-953X

ISSN-L: 2284-9521
Current Trends in Natural Sciences (CD-Rom)

ISSN: 2284-9521

ISSN-L: 2284-9521

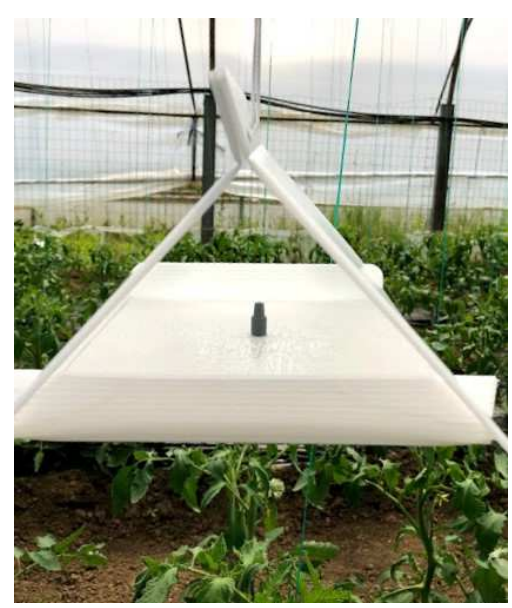

Figure 7. Delta trap placed in the tomato crop

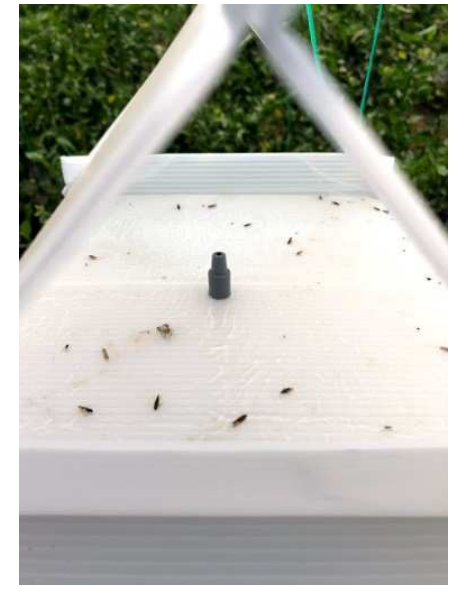

Figure 8. Delta trap with Tuta absoluta captured adults

In laboratory, Macrolophus pygmaeus showed a lower individual predation capacity than Dicyphus bolivari and Dicyphus errans, although in greenhouse trials, it was more effective in controlling $T$. absoluta because of its stronger numerical response (Ferracini et al., 2019; Ingegno et al., 2019).

Macrolophus pygmaeus and Nesidiocoris tenuis demonstrated similar predation characteristics. However, Nesidiocoris tenuis has been shown to be more effective against tomato leafminer as it can consume more eggs at higher pest densities (Ferracini et al., 2019). However, the simultaneous use of the two predatory species can lead to a more effective control at high $T$. absoluta population densities (Michaelides et al., 2018; Ferracini et al., 2019).

In Europe, almost 50 species of Hymenoptera parasitoids have been reported. They belong to the families Eulophidae, Braconidae, Ichneumonidae, Trichogrammatidae, Pteromalidae and Chalcididae in decreasing order of species abundance (Zappalà et al., 2013). Some of these have been tested for their biocontrol potential: Bracon nigricans (Hymenoptera: Braconidae; Biondi et al., 2013), Necremnus tutae (previously mentioned as Necremnus sp. nr. artynes; Bodino et al., 2016; Calvo et al., 2013; Ferracini et al., 2012; Gebiola et al., 2015; Ferracini et al., 2019) and Stenomesius sp. nr. japonicus (Hymenoptera: Eulophidae; Chailleux et al., 2014; Ferracini et al.., 2019), as well as the egg parasitoid Trichogramma achaeae (Hymenoptera: Trichogrammatidae; Cabello et al., 2009; Cascone et al., 2015; Ferracini et al., 2019).

Trichogramma achaeae which parasitizes eggs, is commercially available in Europe and North Africa, may achieve high parasitism rates (>90\%) under greenhouse conditions, both alone and in combination with the predator Nesidiocoris tenuis (Cabello et al., 2009, 2015; Oliveira et al., 2017; Ferracini et al., 2019).

Among the larval parasitoids, Bracon nigricans was tested in laboratory conditions. The wasp showed a good behavioral plasticity in parasitizing the hosts (Ferracini et al., 2019). Females fed either directly on the paralyzed host or inside the leaf mines after building feeding tubes that had been made to reach the tomato leafminer larva (Biondi et al., 2013).

Particular attention has been given to eulophid parasitoids, especially to the genus Necremnus. The efficacy of Necremnus tutae was studied in combination with Nesidiocoris tenuis by Calvo et al. (2013) who observed that predator application prior to planting is sufficient for control (Calvo et al., 2016; Ferracini et al., 2019). In laboratory, Necremnus tutae determined a high mortality of $T$. 
absoluta larvae (Bodino et al., 2018; Ferracini et al., 2012; Ferracini et al., 2019). A good growth rate was obtained at high temperatures $\left(30^{\circ} \mathrm{C}\right)$, suggesting a high potential to reduce the pest in Mediterranean greenhouses with this parasitoids (Calvo et al., 2013; Ferracini et al., 2019). This larval parasitoids was the only one recovered from greenhouses where foliar treatments were made (Zappala et al., 2012c; Ferracini et al., 2019).

In a comparative study, females of Stenomesius sp. nr. japonicus lived longer than those of Necremnus tutae and, as a result, were more effective in terms of the number of parasitized and destroyed larvae. The highest number of offspring was recorded when the wasp developed on 3rdinstar larvae, resulting in larger adults and a higher proportion of females (Chailleux et al., 2014; Ferracini et al., 2019).

Control of T. absoluta infestation is difficult to achieve because the larvae are protected inside the leaf mesophyll or inside the fruit (Cocco et al., 2012).

The main method of controlling this pest is the use of chemicals. However, this method has some disadvantages, such as: destruction of natural predator and parasitoids populations, accumulation of insecticide residues on tomato fruits, rapid development of resistance to insecticides (Braham and Hajji, 2012). The pest has become resistant to most insecticides used, when control products are not alternated. Resistance to abamectin, cartap, metamidophos and permethrin has been demonstrated in Brazil (Siqueira et al., 2000; Abbes et al., 2012). Similarly, T. absoluta showed resistance to abamectin, deltamethrin, and metamidophos in Argentina (Lietti et al., 2005; Abbes et al., 2012) and to organophosphorus insecticides in Bolivia (Moore, 1983; Abbes et al., 2012).

Low efficacy of spinosad has been reported in Chile (Reyes et al., 2012; Abbes, 2012), but Bratu et al. (2015) found that the active substance spinosad (Laser 240 SC) has a high efficacy and a longlasting effect against the tomato leafminer.

The chemical insecticides, approved in Romania to control this pest are Voliam Targo (abamectin $18 \mathrm{~g} / \mathrm{l}+$ chlorantraniliprole $45 \mathrm{~g} / \mathrm{l}$ ) $0.08 \%$, Affirm (emamectin benzoate $0.95 \%$ ) $0.15 \%$, Alverde (metaflumizone $240 \mathrm{~g} / \mathrm{l}$ ) $0.1 \%$ (Costache et al., 2018). It is necessary to respect the preharvest interval.

It is very important to avoid repeated treatments with the same product, by alternating insecticides with different active substances, to preventing the appearance of resistance of the pest to them (Oztemiz, 2014).

An integrated pest control program, based on prophylactic measures (use of "insect-proof" nets, removal of attacked organs, etc.), pheromone traps and the use of chemical treatments, is sufficient to keep the T. absoluta population under effective control. However, an adequate resistance management strategy must be adopted to minimize the risk of dispersal / introduction of resistant populations into new areas of expansion. Moreover, the use of insecticides such as spinosad should be carefully monitored to prevent the emergence and rapid spread of resistance in the new area (Campos et al. 2014; Roditakis et al. 2016; Cherif et al., 2017).

\section{CONCLUSIONS}

Tuta absoluta is an important pest present in tomato crops where can reduce yield by more than $90 \%$, in the absence of adequate control measures. Use of methods to prevent the appearance and spread, such as: use of insect-proof nets, solarization, covering the ground with plastic wrap, destruction of host plants inside and around greenhouses and removal of attacked organs (leaves, fruits), is a first step to avoid the spread of the pest. 


\section{Current Trends in Natural Sciences}

Vol. 9, Issue 17, pp. 222-231, 2020

https://doi.org/10.47068/ctns.2020.v9i17.028

Current Trends in Natural Sciences (on-line)

ISSN: 2284-953X

Current Trends in Natural Sciences (CD-Rom)

ISSN: 2284-9521

ISSN-L: 2284-9521

ISSN-L: 2284-9521

Monitoring the occurrence of the pest attack and the numerical decrease of the populations can be done with pheromone traps.

There are also non-polluting methods such as: treatments with biological products (Laser $240 \mathrm{SC}$ $0.05 \%$, BactoSpeine DF 0.06\%, Oleorgan 0.3\%, Quamar 0.3\%, Konflic 0.3\%) and releasing parasitoids and predators.

The main control method remains the chemical one through treatments with insecticides, as selective as possible against the useful entomofauna (Affirm $0.15 \%$ and Voliam Targo $0.08 \%$ ), by alternation, to prevent the appearance of resistant populations.

Treatments must be applied before the pest penetrates the organs. Chemicals will be used at a medium to high attack intensity, taking into account the preharvest interval. If the attack is incipient, biological products and release of parasitoids and predators can be used.

\section{ACKNOWLEDGEMENTS}

Work carried out within the Sectorial Plan for Rural Research-Development ADER 2020, financed by MADR, Project 7.3.15. "Establishing measures and means for integrated pest prevention and control Tuta absoluta, the tomato leafminer in greenhouse tomato crops" (contract nr. 7.3.15/16.09.2019).

\section{REFERENCES}

Abbes, K., Harbi, A., Chermiti, B. (2012). The tomato leafminer Tuta absoluta (Meyrick) in Tunisia: current status and management strategies. Bulletin OEPP/EPPO Bulletin 42 (2), 226-233, ISSN 0250-8052. DOI: 10.1111/epp.2559.

Abbes, K., Harbi, A., Elimem, M., Hafsi, A., Chermiti, B. (2016). Bioassay of three solanaceous weeds as alternative hosts for the invasive tomato leafminer Tuta absoluta (Lepidoptera:Gelechiidae) and insights on their carry over potential, Afr. Entomol. 24, 334-42.

Aksoy, E., Kovanci, O.B. (2016). Mass trapping low-density populations of Tuta absoluta with various types of traps in field-grown tomatoes. J Plant Dis Prot DOI 10.1007/s41348-016-0003-6.

Altermatt, F., Baumeyer, A., Ebert, D. (2009) Experimental evidence for male biased flight-to-light behavior in two moth species. Entomol Exp Appl 130, 259-265.

Balzan, M.V., Moonen, A.C. (2015). Management strategies for the control of Tuta absoluta (Lepidoptera: Gelechiidae) damage in open $\square$ field cultivations of processing tomato in Tuscany (Italy). EPPO Bulletin. 42, 217-225.

Barrientos, Z.R., Apablaza, H.J., Norero, S.A., Estay, P.P. (1998). Temperatura base y constante termica de desarrollo de la polilla del tomate, Tuta absoluta (Lepidoptera: Gelechiidae). [Base temperature and thermal constant of development of the tomato moth, Tuta absoluta (Lepidoptera: Gelechiidae)]. Ciencia e Investigacion Agraria $25,133-137$.

Batalla-Carrera, L., Morton, A., Garcia-del-Pino, F. (2010). Efficacy of entomopathogenic nematodes against the tomato leafminer Tuta absoluta in laboratory and greenhouse condition. BioControl 55, 523-530, DOI 10.1007/s10526-010-9284-z.

Bayram, Y., Büyük, M., Özaslan, C., Bektaş, Ö., Bayram, N., Mutlu, Ç., Bükün, B. (2015). New host plants of Tuta absoluta (Meyrick) (Lepidoptera: Gelechiidae) in Turkey. Journal of Tekirdag Agricultural Faculty. 22.

Bettaïbi, A., Mezghani-Khemakhem, M., Bouktila, D., Makni, H., Makni, M. (2012). Genetic variability of the tomato leaf miner (Tuta absoluta Meyrick; Lepidoptera: Gelechiidae), in Tunisia, inferred from RAPD-PCR. Chilean Journal of Agricultural Research. 72, 212.

Biondi, A., Desneux, N., Amiens-Desneux, E., Siscaro, G., \& Zappalà, L. (2013). Biology and developmental strategies of the Palaearctic parasitoid Bracon nigricans (Hymenoptera: Braconidae) on the Neotropical moth Tuta absoluta (Lepidoptera: Gelechiidae). Journal of Economic Entomology, 106(4), 1638-1647. 


\section{Current Trends in Natural Sciences}

Vol. 9, Issue 17, pp. 222-231, 2020

https://doi.org/10.47068/ctns.2020.v9i17.028

Current Trends in Natural Sciences (on-line)

ISSN: 2284-953X

Current Trends in Natural Sciences (CD-Rom)

ISSN: 2284-9521

ISSN-L: 2284-9521

ISSN-L: 2284-9521

Biondi, A., Guedes, R.N.C., Wan, F-H., Desneux, N. (2016). Ecology, Worldwide Spread and Management of the Invasive South American Tomato Pinworm, Tuta absoluta: Past, Present and Future. Annual Review of Entomology, 63, 239-58.

Bodino, N., Ferracini, C., Tavella, L. (2016). Is host selection influenced by natal and adult experience in the parasitoid Necremnus tutae (Hymenoptera: Eulophidae). Animal Behaviour, 112, 221-228.

Bodino, N., Ferracini, C., Tavella, L. (2018). Functional response and age-specific foraging behavior of Necremnus tutae and $N$. cosmopterix, native natural enemies of the invasive pest Tuta absoluta in Mediterranean area. Journal of Pest Science. doi:10.1007/s10340-018-1025-6.

Braham, M., Hajji, L. (2012). Management of Tuta absoluta (Lepidoptera, Gelechiidae) with Insecticides on Tomatoes. Insecticides - Pest Engineering, ISBN: 978-953-307895-3.

Bratu, E., Petcuci, A.M., Sovarel, G. (2015). Efficacy of the Product Spinosad an Insecticide Used in the Control of Tomato Leafminer (Tuta absoluta - Meyrick, 1917). BulletinUASVM Horticulture, 72(1), DOI:10.15835/buasvmen-hort:10876.

Cabello, T., Bonfil, F., Gallego, J. R., Fernandez, F. J., Gamez, M., Garay, J. (2015). Can interactions between and omnivorous hemipteran and an egg parasitoid limit the level of biological control for the tomato pinworm. Environmental Entomology, 44, 12-26.

Cabello, T., Gallego, J. R., Vila, E., Soler, A., del Pino, M., Carnero, A. ... Polaszek, A. (2009). Biological control of the South American tomatopinworm, Tuta absoluta (Lep.: Gelechiidae), with releases of Trichogramma achaeae (Hym.: Trichogrammatidae) in tomato greenhouses of Spain. IOBC/WPRS Bulletin, 49, 225-230.

Calvo, F. J., Soriano, J. D., Bolckmans, K., Belda, J. E. (2013). Host instar suitability and lifehistory parameters under different temperature regimes of Necremnus artynes on Tuta absoluta. Biocontrol Science and Technology, 23, 803-815.

Calvo, F. J., Soriano, J. D., Stansly, P. A., Belda, J. E. (2016). Can the parasitoid Necremnus tutae (Hymenoptera: Eulophidae) improve existing biological control of the tomato leafminer Tuta absoluta (Lepidoptera: Gelechiidae). Bulletin of Entomological Research, 106, 502-511.

Campos, M.R., Rodrigues, A.R.S., Silva, W.M., Silva, T.B.M., Silva, V.R.F., Guedes, R.N.C., Siqueira, H.A.A. (2014). Spinosad and the Tomato Borer Tuta absoluta: a bioinsecticide, an invasive pest threat, and high insecticide resistance. PLOS ONE 9(8):e103235.

Caparros Medigo, R., Haubruge, E., Jean Vereggen, F. (2013). Pheromone-based management strategies to control the tomato leafminer, Tuta absoluta (Lepidoptera: Gelechiidae). A review. Biotechnol. Agron. Soc. Environ. 17(3), 475-482.

Cascone, P., Carpenito, S., Slotsbo, S., Iodice, L., Sørensen, J. G., Holmstrup, M., Guerrieri, E. (2015). Improving the efficiency of Trichogramma achaeae to control Tuta absoluta. BioControl, 60(6), 761-771.

Castelo Branco, M. (1992). Flutuacao populacional da traca-do-tomateiro no Distrito Federal. [Tomato leafminer fluctuation in the Federal District]. Horticultura Brasileira, 10, 33-34.

Chailleux, A., Desneux, N., Arnó, J., Gabarra, R. (2014). Biology of two key Palaearctic larval ectoparasitoids when parasitizing the invasive pest Tuta absoluta. Journal of Pest Science, 87(3), 441-448.

Cherif, A., Harbaoui, K., Zappala, L., Grissa-Lebdi, K. (2017). Efficacy of mass trapping and insecticides to control Tuta absoluta in Tunisia. Journal of Plant Diseases and Protection https://doi.org/10.1007/s41348-017-01406.

Cocco, A., Deliperi, S., Delrio. G. (2012). Control of Tuta absoluta (Meyrick) (Lepidoptera: Gelechiidae) in greenhouse tomato crops using the mating disruption technique. J. Appl. Entomol., doi: 10.1111/j.14390418.2012.01735.x.

Costache, M., Şovărel Gabriela, Bratu Elena (2018). Bolile şi dăunătorii culturilor de legume din spaţii protejate. Recunoaştere şi combatere. [Diseases and pests of greenhouse vegetable crops. Recognition and control]. Editura CERES, p. 21-22. 


\section{Current Trends in Natural Sciences}

Vol. 9, Issue 17, pp. 222-231, 2020

https://doi.org/10.47068/ctns.2020.v9i17.028

Current Trends in Natural Sciences (on-line)

ISSN: 2284-953X

Current Trends in Natural Sciences (CD-Rom)

ISSN: 2284-9521

ISSN-L: 2284-9521 ISSN-L: 2284-9521

Cuthbertson, A.G.S., Mathers, J.J., Blackburn, L.F., Korycinska, A., Luo, W., Jacobson, R.J., Northing, P. (2013). Population Development of Tuta absoluta (Meyrick) (Lepidoptera: Gelechiidae) under Simulated UK Glasshouse Conditions. Insects, 4, 185-197; doi:10.3390/insects4020185.

Desneux, N., Luna, M.G., Guillemaud, T., Urbaneja, A. (2011). The invasive South American tomato pinworm, Tuta absoluta, continues to spread in Afro-Eurasia and beyond: The new threat to tomato world production. Journal of Pest Science. 84, 403-408.

Desneux, N., Wajnberg, E., Wyckhuys, K.A.G., Burgio, G., Arpaia, S., Narvaez-Vasquez, C.A., Gonzalez-Cabrera, J., Ruescas D.C., Tabone, E., Frandon, J., Pizzol, J., Poncet, C., Cabello, T., Urbaneja, A. (2010). Biological invasions of European tomato crops by Tuta absoluta: ecology, geographic expansion and prospects for biological control. J. Pest. Sci. 83, 197-215.

Ferracini, C., Bueno V.H.P., Dindo M.L., Ingegno, B.L., Luna, M.G., Salas Gervassio, N.G., Sanchez, N.E., Siscaro, G., van Lenteren, J.C., Zappala, L., Tavella, L. (2019). Natural enemies of Tuta absoluta in the Mediterranean basin, Europe and South Africa. Biocontrol Science and Technology, DOI: 10.1080/09583157.2019.1572711.

Ferracini, C., Ingegno, B. L., Navone, P., Ferrari, E., Mosti, M., Tavella, L., Alma, A. (2012). Adaptation of indigenous larval parasitoids to Tuta absoluta (Lepidoptera: Gelechiidae) in Italy. Journal of Economic Entomology, 105, 1311-1319.

Gebiola, M., Bernardo, U., Ribes, A., Gibson, G. A. P. (2015). An integrative study of Necremnus Thomson (Hymenoptera: Eulophidae) associated with invasive pests in Europe and North America: Taxonomic and ecological implications: An integrative study of Necremnus. Zoological Journal of the Linnean Society, 173, 352-423.

Gontijo, P.C., Picanço, M.C., Pereira, E.J., Martins, J.C., Chediak, M., Guedes, R.N. (2013). Spatial and temporal variation in the control failure likelihood of the tomato leaf miner, Tuta absoluta. Annals of Applied Biology, 162, 50-59.

Haji, F.N.P., Oliveira, C.A., Amorim Neto, M.S., Batista, J.G.S. (1988). Flutuacao populacional da traca do tomateiro no submedio Sao Francisco. [Tomato leafminer fluctuation in the sub-middle Sao Francisco]. Pesquisa Agropecuaria Brasileira, 23, 7-17.

Ingegno, B. L., Messelink, G. J., Bodino, N., Iliadou, A., Driss, L., Woelke, J. B....Tavella, L. (2019). Functional response of the mirid predators Dicyphus bolivari and Dicyphus errans and their efficacy as biological control agents of Tuta absoluta on tomato. Journal of Pest Science. doi:10.1007/s10340-019-01079-8.

Lietti, M.M.M., Botto, E., Alzogaray, R.A. (2005). Insecticide resistance in argentine populations of Tuta absoluta (Meyrick) (Lepidoptera: Gelechiidae). Neotropical Entomology 34, 113-119.

Lopes Filho, F. (1990). Tomate industrial no Submedio Sao Francisco e as pragas que limitam sua producao. [Industrial tomatoes in Submedio Sao Francisco and the pests that limit their production]. Pesquisa Agropecuaria Brasileira, 25, 283-288.

Machekano, H., Mutamiswa, R., Nyamukondiwa, C. (2018). Evidence of rapid spread and establishment of Tuta absoluta (Meyrick) (Lepidoptera: Gelechiidae) in semi-arid Botswana. Agriculture and Food Security 7, 48.

Mansour, R., Brevault, T., Chailleux, A., Cherif, A., Grissa-Lebdi, K., Haddi, K., Mohamed, S.A., Nofemela, R.S., Oke, A., Sylla, S., Tonnang, H.E.Z., Zappala, L., Kenis, M., Desneux, N., Biondi, A. (2018). Occurrence, biology, natural enemies and management of Tuta absoluta in Africa. Entomologia Generalis, Vol. 38, Issue 2, 83-112.

Martins, J.C., Picanco, M.C., Bacci, L., Guedes, R.N.C., Santana Jr., P.A., Ferreira, D.O., Chediak, M. (2016). Life table determination of thermal requirements of the tomato borer Tuta absoluta. J Pest Sci, DOI 10.1007/s10340-016-0729-8.

Michaelides, G., Sfenthourakis, S., Pitsillou, M., Seraphides, N. (2018). Functional response and multiple predator effects of two generalist predators preying on Tuta absoluta eggs. Pest Management Science, 74(2), 332-339.

Mohamadi, P., Razmjou, J., Hassanpour, M. (2017). Population Growth Parameters of Tuta absoluta (Lepidoptera: Gelechiidae) on Tomato Plant Using Organic Substrate and Biofertilizers. Journal of Insect Science, 17(2), 36; 1-7, doi: 10.1093/jisesa/iex011. 


\section{Current Trends in Natural Sciences}

Vol. 9, Issue 17, pp. 222-231, 2020

https://doi.org/10.47068/ctns.2020.v9i17.028

Current Trends in Natural Sciences (on-line)

ISSN: 2284-953X

Current Trends in Natural Sciences (CD-Rom)

ISSN: 2284-9521

ISSN-L: 2284-9521

ISSN-L: 2284-9521

Moore, J.E. (1983). Control of tomato leafminer (Scrobipalpula absoluta) in Bolivia. Tropical Pest Management 29, 231-238.

Moreno, S.C., Silverio, F.O., Picanco, M.C., Alvarenga, E.S., Pereira, R.R., Santana Junior, P.A., Silva, G.A. (2017). New Pyrethroids for Use Against Tuta absoluta (Lepidoptera: Gelechiidae): Their Toxicity and Control Speed. Journal of Insect Science, 15(5), 99; 1-6, doi: 10.1093/jisesa/iex072.

Oliveira, L., Durão, A. C., Fontes, J., Roja, I. S., Tavares, J. (2017). Potential of Trichogramma achaeae (Hymenoptera: Trichogrammatidae) in biological control of Tuta absoluta (Lepidoptera: Gelechiidae) in Azorean greenhouse tomato crops. Journal of Economic Entomology, 110(5), 2010-2015.

Oztemiz, S. (2014). Tuta absoluta Povolny (Lepidoptera: Gelechiidae), the exotic pest in Turkey. Rom. J. Biol. - Zool., Volume 59, No 1.

Reyes, M., Rocha, K., Alarcon, L., Siegwart, M., Sauphanor, B. (2012). Metabolic mechanisms involved in the resistance of field populations of Tuta absoluta (Meyrick) (Lepidoptera: Gelechiidae) to spinosad. Pesticide Biochemistry and Physiology 102, 45-50.

Roditakis, E., Steinbach, D., Moritz, G.B., Nauen, R. (2016). Ryanodine receptor point mutations confer diamide insecticide resistance in tomato leafminer, Tuta absoluta (Lepidoptera: Gelechiidae). Insect Biochem Mol Biol. https://doi.org/10.1016/j.ibmb.2016.11.003

Sinclair, R.J., Hughes, L. (2010). Leaf miners: The hidden herbivores. Austral Ecology. 35, 300-313.

Siqueira, H.A., Guedes, R.N., Picanco, M.C. (2000). Insecticide resistance in populations of Tuta absoluta (Lepidoptera: Gelechiidae). Agricultural and Forest Entomology 2, 147-153.

Souza, J.C., Reis, P.R. (1992). Traca-do-tomateiro: historico, reconhecimento, biologia, prejuizos e controle. [Tomato leafminer: history, recognition, biology, damage and control]. EPAMIG, Boletim Tecnico, n.38, 19 pp.

Torres, J.B., Faria, C.A., Evangelista Jr., W.S., Pratissoli, D. (2001). Within-plant distribution of the leaf miner Tuta absoluta (Meyrick) immatures in processing tomatoes, with notes on plant phenology. International Journal of Pest Management, 47:3, 173-178, DOI: 10.1080/02670870010011091,

Tropea, G.G., Siscaro, G., Biondi, A., Zappalà, L. (2012). Tuta absoluta, a South American pest of tomato now in the EPPO region: Biology, distribution and damage. EPPO Bulletin. 42, 205-210.

Zappala, L., Biondi, A., Alma, A., Al-Jboory, I. J., Arno, J., Bayram, A., Chailleux, A., El-Arnaouty, A., Gerling, D., Guenaoui, Y., Shaltiel-Harpaz, L., Siscaro, G., Stavrinides, M., Tavella, L., Vercher Aznar, R., Urbaneja, A., Desneux, N. (2013). Natural enemies of the South American moth, Tuta absoluta, in Europe, North Africa and Middle East, and their potential use in pest control strategies. J Pest Sci, 86, 635-647 DOI 10.1007/s10340013-0531-9.

Zappalà, L., Biondi, A., Siscaro, G., Garzia, G. T., van Achterberg, K., Desneux, N. (2012c). Adattamento di limitatori indigeni di Tuta absoluta in Italia: Il parassitoide Bracon nigricans. [Adaptation of indigenous limiters of Tuta absoluta in Italy: The parasitoid Bracon nigricans]. Atti Dell'Accademia Nazionale Italiana di Entomologia Rendiconti, 60, 85-94.

Zekeya, N., Chacha, M., Ndakidemi, P.A., Materu, C., Chidege, M., Mbega, E.R. (2017). Tomato Leafminer (Tuta absoluta Meyrick 1917): A Threat to Tomato Production in Africa. JAERI, 10(1), 1-10, Article no.JAERI.28886 ISSN: 2394-1073. 